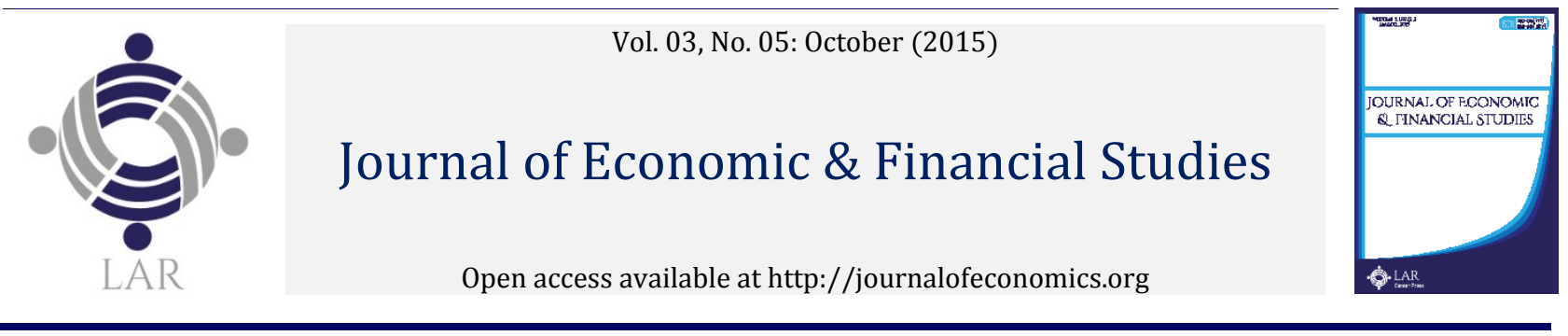

\title{
A non-parametric approach to innovation gaps and economic growth
}

\author{
J. R. Perilla Jimenez $\mathrm{a}^{*}$ \\ a Maastricht University \& University of Groningen, Netherlands. \\ *Corresponding author's email address: j.perillajimenez@maastrichtuniversity.nl
}

\section{A R T I C L E IN F O}

Received: 24-01-2014

Revised resubmit: 20-06-2015

Accepted: 28-07-2015

Available online: 03-10-2015

Keywords:

Economic growth;

Innovation gaps;

Non-parametric approach.

\begin{abstract}
A B S T R A C T
A non-parametric approach based on DEA techniques is used to dis- entangle the relationship between innovation growth and per-capita GDP growth in a sample of 30 countries during 1996-2008. The decomposition of GDP-growth brings support to the notion of advantage of backward- ness. It leads to conclude that, in the context of innovation, both the process of catching-up and technological change play an important explanation of the dynamics of economic growth. This is in sharp contrast to alternative evidence that brings more support to the importance of capital deepening in explaining labour growth productivity.
\end{abstract}

JEL Classification: C23; 041; 043.

(C) 2015 The Authors. This is an open access article under the terms of the Creative Commons Attribution License 4.0, which allows use, distribution and reproduction in any medium, provided the original work is properly cited.

DOI: $10.18533 /$ jefs.v3i05.26

\subsection{Introduction}

The measurement and impact of technology differences on economic growth is one of the never end debates in economics. ${ }^{1}$ Yet, the advantage of backward- ness hypothesis, earlier put by economic historians, ${ }^{2}$ has been argued time and again - in endogenous growth models - as a theoretical possibility to under- stand the workings of the relationship between technology and growth. ${ }^{3}$ In a nutshell, this hypothesis predicts higher rates of economic growth for countries with comparatively larger technology gaps. It happens because latecomer countries have the possibility to profit on the adoption and imitation of technology developments by countries at the frontier. As a corollary, the leading countries are predicted to grow only based on their innovative effort and the ability to push further the world technology frontier. Thus, as countries approach to the frontier, innovation becomes the most important engine of economic growth.

\footnotetext{
${ }^{1}$ For a discussion see Nelson and Phelps (1966), Nelson and Pack (1999), Bernard and Jones (1996).

${ }^{2}$ see Gerschenkron (1962), and Abramovitz (1986).

${ }^{3}$ For Examples on this literature see Aghion and Howitt 2009 Ch 4 \& 5, Acemoglu 2009 Ch 18 \& 22, Acemoglu, Zilibotti and Aghion (2006), and Aghion and Howitt (2006).
} 
This interpretation, nevertheless, leads to the unappealing implication that innovation is exclusive to countries at the world frontier. A more flexible interpretation has been put recently by Aghion and Howitt (2006). In this view, the advantage of backwardness arises from the fact that implementation of innovations developed elsewhere allows a given country to make larger quality improvements the further it has fallen behind the frontier. Conversely, as the economy approaches to the frontier only leading-edge innovations - a leapfrog over current developments - can affect its growth performance.

This paper is purported to empirically evaluate this hypothesis. To this end, I relate technology to innovation and analyse the relationship between innovative efforts and economic growth. In the analysis, I make use of a nonparametric approach based on Data Envelopment Analysis (DEA) techniques. ${ }^{4}$ The relationship between innovation and per-capita growth is based on a decomposition similar to that proposed in recent research by Kumar and Russell (2002), and Los and Timmer (2005). I obtain measures of country population and PPP adjusted real GDP (Base 1990) using the estimates of that are available from the Groningen Growth Development Center (GGDC). The measure of innovation is summarized by an index on five variables that capture diverse aspects of the innovative activity. These are drawn from the Science and Technology indicators released through the World Bank Development Indicators (WDI), and the World Intellectual Property Organization (WIPO). Data coverage allows the selection of 30 countries with yearly information between 1996-2008 for all variables of interest.

The rest of the paper proceeds as follows. In section 2, I provide a brief insight on the theoretical background that underlines the advantage of backwardness. In Section 3, I present the methodology to decompose GDP-growth into components of catching-up, technical change, and knowledge investments. In section 4, I introduced the data and present a glimpse on the relationship between innovation growth, and economic growth. In section 5, I present the results of the DEA analysis and discuss the implications, and in section 6 some concluding remarks are offered.

\subsection{Theory}

The key insight in endogenous growth models that highlight the advantage of backwardness is that economic growth depends on the characteristics of the economic environment. Catching-up by adoption and imitation of frontier technologies requires a different institutional setting in backward countries relative to the more advanced economies. Diversification from traditional to modern forms of production, and technology upgrading, are hard to emerge by themselves at low levels of development. To ease the change, backward countries typically are faced to set "non competitive" arrangements and state interventions that might facilitate risky investments. A restrictive institutional environment, nevertheless, is hold as inappropriate at higher states of development. As the economy approaches to the world technology frontier, governments are faced to the need to develop a different institutional framework. The new arrangement and set of policies should be more akin to encourage innovation, i.e., property rights institutions and market competition. Innovation requires competition because if forces firms within the country to reduce costs and to produce better products and services.

Aside of the institutional environment that propels the innovation effort, there are two main inputs to innovation; namely, the investment expenditures made by the prospective innovator, and the stock of innovations that have already been made by past innovators. The latter input constitutes the publicly available stock of knowledge to which current innovators are hoping to add. The theory is hugely flexible in interpreting the workings of innovation. It encompasses the case of successful innovators that may leapfrog the best technology available and push the frontier. But also the case of innovators that catch up to the frontier, which represents the stock of knowledge available to innovations in all sectors of all countries. Aghion and Howitt (2006) stress on both these cases to highlight that innovation may imply either a leadingedge activity that pushes the technology frontier or the effort to implementing technologies that have been developed elsewhere. Innovations then interact with each other in different ways and in different countries, and are highly dependent on the specifics of institutional arrangements.

In this paper I follow a simplified version of the model proposed by Aghion and Howitt (2006). Formally, let $\omega>1$ be the factor by which new leading-edge innovation are created, i.e., $A t+1=\omega A_{t}$, and let $\bar{A}$ be the state of accumulated knowledge at the world technology frontier. For a given country, the rate of change of productivity that is associated to innovation is given by

${ }^{4}$ See Coelli et al (2005). I make use of the DEAP software developed by this author. See Barr(2005) for a review of alternative optimization packages 
$A_{\mathbf{t}+1}-A_{\mathbf{t}}=\theta(\mathrm{h})\left[\mathrm{a}(\omega-1) A_{\mathbf{t}}+\mathrm{b}\left(\overline{\mathrm{A}}-\mathrm{A}_{\mathbf{t}}\right)\right]$

where $h$ denotes the degree of institutional quality, and $a$ and $b$ are parameters that respectively denote the frequency at which leading innovation and implementation of existing innovations take place. In this equation, the first term in the summation within the square brackets on the right hand side captures the effect of leading edge innovations. The second captures the effect of innovation implementation or catching up. This model relates the rate of growth of the economy to the rate of growth of productivity, which is given by

$$
g_{t}=\frac{A_{t+1}-A_{t}}{A_{t}}=\theta(h)\left[a(\omega-1)+b\left(F_{t}^{-1}-1\right)\right]
$$

where $F_{t}=A_{t} / \bar{A}$ is an inverse measure of distance to the world technology frontier. It accounts for the fact that the further a given country is behind the frontier (the smaller is $F_{\mathbf{t}}$ ), the faster it will grow through innovation implementations if the backwardness advantage holds. Conversely, the shorter the distance to the frontier, the lower the room to profit on implementation. In the extreme case when a country reaches the frontier, such that $A_{t}=\bar{A}$ the second term in the equation vanishes. In that case, the only source of growth is by pushing forward the world frontier. ${ }^{5}$

\subsection{Methodology}

The decomposition of productivity growth proposed by Kumar and Rusell (2002), and Los and Timmer (2005), is well suited to analyses how economic growth is related to innovative efforts and distance to the frontier. Though it has turned to be current practice to use labour productivity in this decomposition, I use percapita GDP values instead. While using" population" rather than "workers" leads to a difference in scale, I consider conceptually more interesting the analysis of per-capita growth from a development point of view. ${ }^{6}$

Thus, I refer to the output-oriented estimation of efficiency frontiers, and the decomposition of (per-capita) GDP growth changes in terms of "catching-up" (changes in efficiency that are given by movements towards or away from the frontier), technical change (movements of the efficiency frontier led by leapfrog innovations), and "knowledge investment" (movements along the efficiency frontier). Denote as Fyz the distance from yperiod observations to the frontier formed by z-period observations. In terms of figure 1, the decomposition is based on "Fisher Ideal" geometric means of the following distances.

$$
\begin{aligned}
& \frac{y_{2}}{y_{1}}=\left(\frac{y_{2}}{F_{22}} \times \frac{F_{11}}{y_{1}}\right) \times\left(\frac{F_{22}}{F_{21}} \times \frac{F_{12}}{F_{11}}\right)^{0.5} \times\left(\frac{F_{21}}{F_{11}} \times \frac{F_{22}}{F_{12}}\right)^{0.5} \\
& =(\text { Catching }- \text { up }) \times(\text { Tech }- \text { Change }) \times(\mathrm{K}-\text { Investments })
\end{aligned}
$$

The estimation of, and the distance of each country to, the frontier, is based on DEA techniques. This method has turned to be widely used to construct Malmquist productivity indices, and decompose them into the three components above. This decomposition is based on the assumptions of constant returns to scale. ${ }^{7}$

DEA techniques have been widely used at both micro and macroeconomic settings to study firm and crosscountry productivity performance respectively. In those approaches the idea is to see, for instance, the optimal amount output that is attainable given a combination of inputs. In this paper, I propose a slightly different view. The idea is to capture the link between wide economy output and innovative activity. Accordingly with the theoretical insights in the previous section, to construct the world technology frontier I use the (inverse) of an index that summarizes a range of technologies related to innovation. This is consistent with the fact that the frontier is determined by countries with the highest levels of innovation and highest levels of output. The data and construction of this index are explained in next section.

\footnotetext{
${ }^{5}$ For a more detailed version of the model presented here see at Aghion and Howitt (2006), and Aghion and Howitt (2009), Ch. 4.

${ }^{6}$ Note that the share of labour force on population has tended to be more or less constant over long periods (see for example Elsby, Michaels, and Solon (2009). The remark in using population figures is that productivity changes, e.g., due to the increase in unemployment during crisis episodes, can not captured.

${ }^{7}$ The approach consists on the calculation of the frontiers and relevant distances on pairs of consecutive years. For each pair of years, two indices are constructed (each one taking as base the technology of the other respectively). Then a geometric mean is calculated between the two. The change in the technology of reference is purported to reduce the bias caused by the choice of the base period (See Coelli et al 2005).
} 
Figure 1: GDP-Growth Decomposition

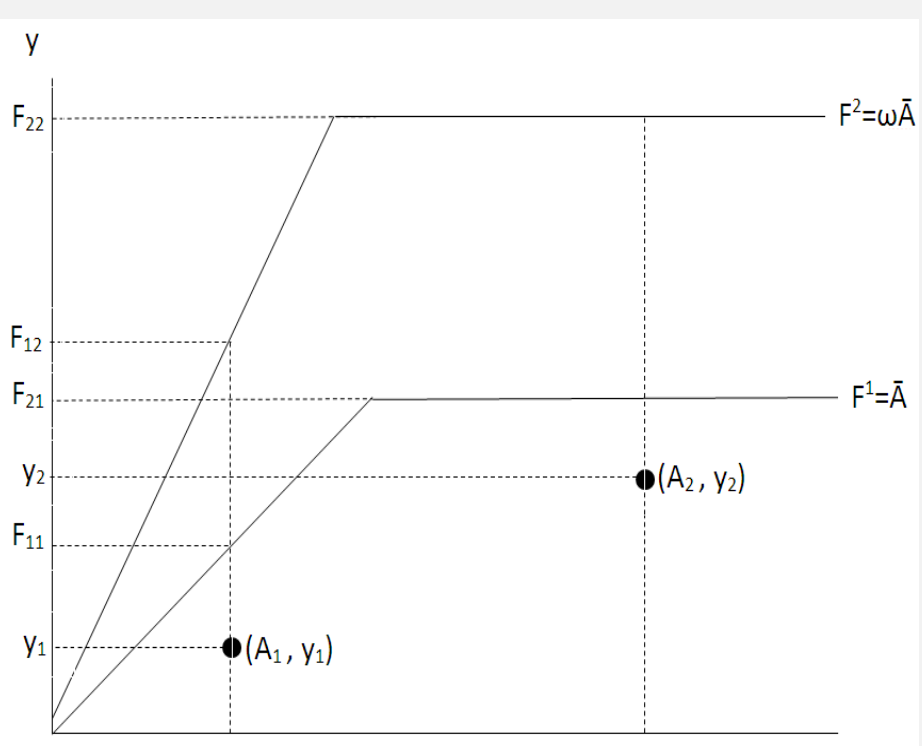

A

\subsection{Data}

The data on diverse forms of innovation are obtained from the Science and Technology, datasets that are available from the WDI, and supplemented with data released by WIPO.8 PPP adjusted real GDP (Base 1990) and population are obtained from the GGDC. ${ }^{9}$ The period of analysis is restricted to 1996-2008 to ensure a consistent dataset with yearly observations on each variable of interest. ${ }^{10}$

The sample of technologies related to innovation includes a set of 5 activities. (Table $1 \mathrm{~A}$ in the appendix presents a description of these technologies). The 30 countries in the analysis are selected on base of the availability of information on the same range of innovative activities and the time period. (See Table $2 \mathrm{~A}$ in the appendix.)

The measure of innovation that I use mimics the standard practice to develop a synthetic indicator to capture the various aspects that feature the technological capability of a country. ${ }^{11}$ It is estimated each year as the arithmetic mean of the normalized values for the five innovation activities. It implies that the same weight is given to each innovation activity. For each variable, the normalization is carried out with respect to the corresponding value for the 30 countries in the sample.

\section{Some Correlation Patterns}

Table 1 shows the 1996-2008 average rates of GDP and innovation growth (both measured in percapita terms) for the sample of 30 countries. At first sight there is only a slight difference in the GDPgrowth achievements of the innovation decreasing and innovation increasing economies. The difference in the average GDP-growth goes initially from $3.35 \%$ to $3.88 \%$ between both groups. But that result is largely influenced by the high rates of innovation and GDP growth of China. When this country is excluded, the difference between groups reduces to 0.3 percentage points, from $3.35 \%$ to $3.65 \%$.

\footnotetext{
${ }^{8}$ See http://data.worldbank.org/topic/science-and-technology, and http://www.wipo.int/ipstats/en/.

${ }^{9}$ See at http://www.rug.nl/research/ggdc/

${ }^{10}$ Data coverage is an important limitation in this analysis, and this is mainly true for information on R\&D. Whilst this is a key proxy for innovation, it is only available from the World Bank from 1996 onwards. Other forms of innovation, like patents application, are available for a larger set of countries and years. Nevertheless, I consider more convenient to rely on an average over different sources than a single statistics. Though single variables can shed light on specific aspects of innovative patterns, separately they provide an incomplete view.

${ }^{11}$ For an overview of these practices see, for instance, Archibugi, Denni, and Filippetti (2009).
} 


\begin{tabular}{|c|c|c|c|}
\hline \multicolumn{4}{|c|}{ Table 1: GDP-Growth and Innovation-Growth (Average 1996-2008) } \\
\hline HICs & Countries & GDP growth & Innovation growth \\
\hline & Argentina & 2.61 & 1.53 \\
\hline \multirow[t]{2}{*}{1} & Austria & 2.25 & -0.36 \\
\hline & Belarus & 8.35 & 3.14 \\
\hline \multirow[t]{2}{*}{1} & Belgium & 2.10 & -1.64 \\
\hline & Bulgaria & 5.24 & 0.10 \\
\hline \multirow[t]{3}{*}{1} & Canada & 2.28 & 1.08 \\
\hline & China & 7.35 & 15.70 \\
\hline & Colombia & 1.36 & 2.52 \\
\hline 1 & Czech Republic & 3.22 & -2.41 \\
\hline 1 & Finland & 3.41 & -0.58 \\
\hline 1 & France & 1.56 & -2.14 \\
\hline 1 & Germany & 1.49 & -0.40 \\
\hline 1 & Hungary & 4.12 & -0.50 \\
\hline 1 & Ireland & 5.09 & -0.01 \\
\hline 1 & Israel & 1.51 & 1.70 \\
\hline \multirow[t]{3}{*}{1} & Japan & 0.86 & -1.50 \\
\hline & Latvia & 8.02 & -0.73 \\
\hline & Lithuania & 6.44 & 5.48 \\
\hline 1 & Poland & 4.57 & 0.24 \\
\hline \multirow[t]{3}{*}{1} & Portugal & 1.57 & 4.25 \\
\hline & Romania & 3.43 & 0.03 \\
\hline & Russian Federation & 5.85 & 2.25 \\
\hline $1^{*}$ & Singapore & 3.11 & -0.72 \\
\hline 1 & Slovak Republic & 4.88 & -5.28 \\
\hline 1 & Slovenia & 4.41 & -0.34 \\
\hline 1 & South Korea & 3.83 & 4.10 \\
\hline \multirow[t]{2}{*}{1} & Spain & 3.43 & 0.47 \\
\hline & Turkey & 2.52 & 7.13 \\
\hline 1 & United Kingdom & 2.34 & -2.45 \\
\hline \multirow[t]{4}{*}{1} & United States & 1.79 & 1.03 \\
\hline & Inn. Increasing Economies (1) & 3.88 & 3.17 \\
\hline & Inn. Increasing Economies (2) & 3.65 & 2.34 \\
\hline & Inn. Decreasing Economies & 3.35 & -1.36 \\
\hline
\end{tabular}

Source: Author's elaboration based on GGDC, WDI, and WIPO statistics.

Note: The column HICs highlights countries classified High income by the OCED. The exception is Singapore, which is classified as nonOECD High income. All figures are in per capita terms. GDP is PPP adjusted.

(1) Includes all economies that show increasing rates of innovation.

(2) Includes economies that show increasing rates of innovation but suppressing China.

(3) Includes all economies that show decreasing rates of innovation.

Whilst, in light of the theory, one would expect that more advanced economies show positive rates of innovation growth, the figures in the table are counterfactual. Most of the countries considered High Income, under the OECD standards of classification, show negative rates of innovation growth. The key exceptions are given by some of the usual suspects: Canada, South Korea, and the United States. But the positive growing innovation group includes also the less developed countries in the sample.

Another key fact in the data is related to correlation patterns between GDP growth and innovation growth. At first sigh this correlation is relatively larger for the countries showing increasing rates of innovation (39.4 Vs. 4.2), but the difference is clearly influenced by the inclusion of China. When this country is excluded the correlation for the increasing innovation group reduces largely (7.6). These patterns are clearly appreciated in the slope differences that are shown in figure 2.

To summarize, at first sight the evidence in support of the backwardness hypothesis in the context of innovation is weak. This may seem cumbersome even for the low number of countries and the short period of time under analysis, and warrants the decomposition analysis that was proposed in the previous section. 
Figure 2: GDP-growth and innovation-growth correlation patterns

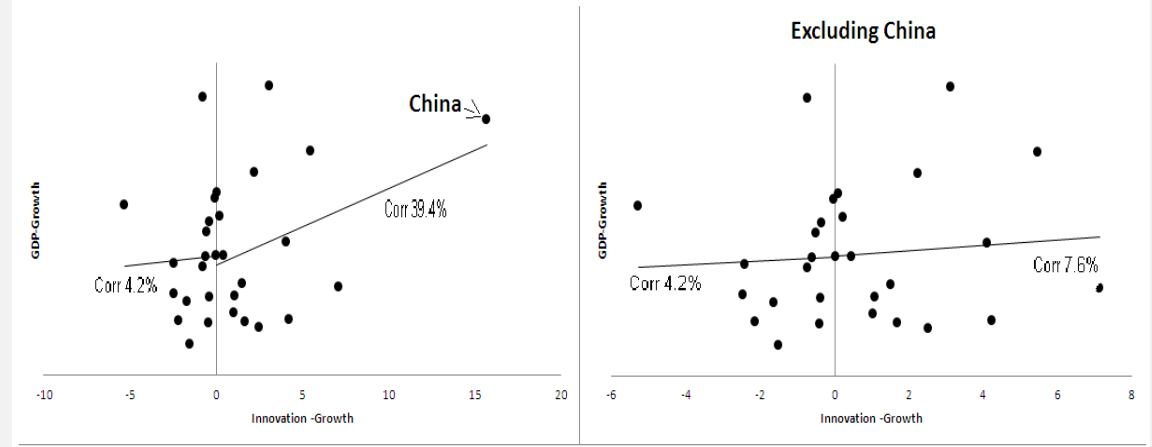

\subsection{Results}

Table 2 provides the estimation of the distance to the efficiency frontiers for each country between 19962008. Consistent with the DEA analytical framework and the theoretical background in the simple model introduced above whereas leading countries operate on the frontier, i.e., the term $\mathrm{Ft}=\mathrm{At} / \mathrm{A}^{-}=1$, backward countries operate beneath it, i.e., $\mathrm{Ft}<1$.

In 1996 just two countries: Japan and the US, determine the frontier and figure as the innovation leaders. But the set of leading innovators increases through 2008 to include Canada, China, Ireland, and Singapore. Within this list, The largest increase in the efficiency index is observed for China. Whilst through 1996-1997 this country was far away from the world technology frontier, by 2002 it became one of the leading innovators.

Remarkably, the change from backwardness to leading-edge innovator coincides with the ascension of the country to the World Trade Organization and the huge subsequent achievements in diverse economic aspects that it experienced. In terms of the exposition in this paper the case of China is paradigmatic. It amounts to the largest process of catching-up in the sample of 30 countries, which is summarized in table 2 by the change in efficiency scores from 0.31 in 1996 to 1.00 in 2002-2008.

In the same line of analysis it can be seen that further cases of catching-up are Belarus (whose efficiency scores between 1996-2008 go from 0.23 to 0.45), Latvia (0.29 to 0.53), and to a less extent Russian Federation (0.22 to 0.39). By contrast, a loss of efficiency that amounts to reduction in the process of catching-up is observed for three countries: Austria (0.89 to 087), Colombia (0.26 to 0.24), and Portugal ( 0.58 to 0.52 ). There are also two cases of countries that move away from the frontier (Singapore in 20002001, and Ireland in 2007-2008).

One can go further in the analysis of the performance of the leading countries reported in table 2 . As is discussed by Los and Timmer (2005), the availability of panel data information allows the construction of an "intertemporal reference production set" (IRPS) consisting of the frontier constructed with the whole available information. The last column in table 2 summarizes the result of doing so. ${ }^{12}$ From this point of view the frontier in the year 2008 is formed by the innovative performance and growth standards observed for Japan in 1996 and through 2006-2008; Canada, Ireland, and Singapore in 2007; and China and US in 2008. In other words, in these years these countries achieve the maximum levels of GDP given their levels of innovation.

${ }^{12}$ It is, whilst the usual practice is to construct the frontier of a given year using only the information of the same year, the IRPS amounts to estimate, in this case, the efficiency frontier of 2008 using all available information since 1996. 
The contribution of the process of catching-up, jointly with the other terms in the decomposition that explains per-capita GDP growth, is summarized in table 3. The decomposition is an average of the changes between 1996-2008. Accordingly, with the efficiency scores discussed above, the largest process of catching up corresponds to China, (10.3\%). Nor surprisingly, given their efficiency scores, the most successful cases include also Belarus (5.6\%), Latvia (5.2\%), and Russian Federation (4.8\%). But catching up is an important component of the GDP-growth performance for most of the other countries too. The few exceptions in the table are given by Austria, Colombia, Israel, and Portugal. As the figures in the table suggest, through the years these countries keep moving further away of the frontier.

\begin{tabular}{|c|c|c|c|c|c|c|c|c|c|c|c|c|c|c|}
\hline Country & 1996 & 1997 & 1998 & 1999 & 2000 & 2001 & 2002 & 2003 & 2004 & 2005 & 2006 & 2007 & 2008 & Leaders \\
\hline Argentina & 0.400 & 0.428 & 0.444 & 0.405 & 0.381 & 0.359 & 0.310 & 0.331 & 0.349 & 0.368 & 0.386 & 0.401 & 0.432 & \\
\hline Austria & 0.893 & 0.912 & 0.943 & 0.930 & 0.920 & 0.920 & 0.901 & 0.898 & 0.894 & 0.891 & 0.874 & 0.849 & 0.871 & \\
\hline Belarus & 0.234 & 0.262 & 0.286 & 0.283 & 0.287 & 0.301 & 0.305 & 0.321 & 0.349 & 0.371 & 0.389 & 0.401 & 0.448 & \\
\hline Belgium & 0.891 & 0.921 & 0.940 & 0.925 & 0.918 & 0.920 & 0.906 & 0.902 & 0.905 & 0.902 & 0.890 & 0.870 & 0.888 & \\
\hline Bulgaria & 0.234 & 0.224 & 0.236 & 0.233 & 0.237 & 0.249 & 0.254 & 0.262 & 0.272 & 0.282 & 0.287 & 0.289 & 0.316 & \\
\hline Canada & 0.934 & 0.967 & 1.000 & 1.000 & 1.000 & 1.000 & 1.000 & 1.000 & 1.000 & 1.000 & 1.000 & 1.000 & 1.000 & $\begin{array}{c}\text { Canada } \\
2007\end{array}$ \\
\hline China & 0.310 & 0.339 & 0.458 & 0.525 & 0.623 & 0.822 & 1.000 & 1.000 & 1.000 & 1.000 & 1.000 & 1.000 & 1.000 & $\begin{array}{l}\text { China } \\
2008\end{array}$ \\
\hline Colombia & 0.261 & 0.261 & 0.259 & 0.233 & 0.226 & 0.224 & 0.219 & 0.223 & 0.224 & 0.228 & 0.234 & 0.238 & 0.245 & \\
\hline $\begin{array}{l}\text { Czech } \\
\text { Republic }\end{array}$ & 0.426 & 0.425 & 0.422 & 0.409 & 0.407 & 0.416 & 0.412 & 0.421 & 0.428 & 0.443 & 0.446 & 0.445 & 0.459 & \\
\hline Finland & 0.788 & 0.836 & 0.883 & 0.874 & 0.878 & 0.896 & 0.882 & 0.876 & 0.886 & 0.880 & 0.866 & 0.848 & 0.868 & \\
\hline France & 0.886 & 0.884 & 0.962 & 0.939 & 0.915 & 0.982 & 0.964 & 0.936 & 0.904 & 0.955 & 0.923 & 0.902 & 0.906 & \\
\hline Germany & 0.826 & 0.886 & 0.888 & 0.881 & 0.930 & 0.930 & 0.924 & 0.896 & 0.867 & 0.862 & 0.887 & 0.881 & 0.885 & \\
\hline Hungary & 0.283 & 0.298 & 0.314 & 0.313 & 0.317 & 0.329 & 0.335 & 0.345 & 0.352 & 0.355 & 0.348 & 0.332 & 0.338 & \\
\hline Ireland & 0.748 & 0.831 & 0.886 & 0.923 & 0.957 & 1.000 & 1.000 & 1.000 & 1.000 & 1.000 & 1.000 & 1.000 & 0.993 & $\begin{array}{c}\text { Ireland } \\
2007\end{array}$ \\
\hline Israel & 0.726 & 0.734 & 0.737 & 0.706 & 0.719 & 0.697 & 0.661 & 0.653 & 0.658 & 0.663 & 0.657 & 0.643 & 0.662 & \\
\hline Japan & 1.000 & 1.000 & 1.000 & 1.000 & 1.000 & 1.000 & 1.000 & 1.000 & 1.000 & 1.000 & 1.000 & 1.000 & 1.000 & $\begin{array}{c}\text { Japan } \\
\text { 2006-08 }\end{array}$ \\
\hline Latvia & 0.287 & 0.314 & 0.334 & 0.331 & 0.342 & 0.370 & 0.377 & 0.395 & 0.435 & 0.463 & 0.502 & 0.529 & 0.527 & \\
\hline Lithuania & 0.261 & 0.280 & 0.301 & 0.283 & 0.282 & 0.299 & 0.305 & 0.325 & 0.338 & 0.349 & 0.362 & 0.376 & 0.403 & \\
\hline Poland & 0.288 & 0.308 & 0.325 & 0.325 & 0.325 & 0.328 & 0.324 & 0.333 & 0.343 & 0.348 & 0.360 & 0.370 & 0.396 & \\
\hline Portugal & 0.579 & 0.602 & 0.628 & 0.619 & 0.613 & 0.620 & 0.604 & 0.588 & 0.579 & 0.565 & 0.539 & 0.517 & 0.524 & \\
\hline Romania & 0.160 & 0.151 & 0.144 & 0.136 & 0.134 & 0.141 & 0.144 & 0.149 & 0.158 & 0.161 & 0.168 & 0.167 & 0.181 & \\
\hline $\begin{array}{l}\text { Russian } \\
\text { Federation }\end{array}$ & 0.224 & 0.229 & 0.217 & 0.229 & 0.250 & 0.265 & 0.277 & 0.290 & 0.302 & 0.308 & 0.331 & 0.360 & 0.394 & \\
\hline Singapore & 0.949 & 0.998 & 0.963 & 0.968 & 1.000 & 0.958 & 0.931 & 0.927 & 0.966 & 0.992 & 1.000 & 1.000 & 1.000 & $\begin{array}{c}\text { Singapore } \\
2007\end{array}$ \\
\hline $\begin{array}{l}\text { Slovak } \\
\text { Republic }\end{array}$ & 0.357 & 0.374 & 0.395 & 0.378 & 0.365 & 0.375 & 0.375 & 0.381 & 0.383 & 0.386 & 0.401 & 0.402 & 0.464 & \\
\hline Slovenia & 0.523 & 0.548 & 0.569 & 0.574 & 0.572 & 0.585 & 0.574 & 0.578 & 0.584 & 0.582 & 0.591 & 0.601 & 0.647 & \\
\hline South Korea & 0.608 & 0.633 & 0.596 & 0.634 & 0.672 & 0.701 & 0.732 & 0.735 & 0.746 & 0.770 & 0.784 & 0.816 & 0.835 & \\
\hline Spain & 0.636 & 0.661 & 0.691 & 0.689 & 0.695 & 0.715 & 0.715 & 0.728 & 0.734 & 0.744 & 0.756 & 0.756 & 0.778 & \\
\hline Turkey & 0.294 & 0.311 & 0.316 & 0.283 & 0.287 & 0.260 & 0.269 & 0.278 & 0.291 & 0.305 & 0.314 & 0.314 & 0.319 & \\
\hline $\begin{array}{l}\text { United } \\
\text { Kingdom }\end{array}$ & 0.907 & 0.906 & 0.904 & 0.964 & 0.941 & 0.937 & 0.999 & 0.973 & 0.942 & 0.999 & 0.967 & 0.949 & 0.952 & \\
\hline $\begin{array}{l}\text { United } \\
\text { States }\end{array}$ & 1.000 & 1.000 & 1.000 & 1.000 & 1.000 & 1.000 & 1.000 & 1.000 & 1.000 & 1.000 & 1.000 & 1.000 & 1.000 & US 2008 \\
\hline
\end{tabular}

On the other side, since catching-up is less important for countries on or near the world frontier, column 4 of table 3 consistently suggest a larger contribution of the technical change component for these countries. By lack of a better terminology, I associate technical change with the upsurge of leading innovations. The interpretation conforms well with the size of this component in explaining the GDPgrowth performance of some countries near the frontier in table 2: Canada, Singapore, Ireland, UK, US, Belgium. Remarkable, whilst it falls short of the frontier, Austria also features among the most successful innovators. 
Nevertheless, it may appear awkward that the less successful Colombia and Portugal show up with large scores of technical change. The insight in this case is that in the innovation race backward countries gain not only by catching-up (it is, through a reduction of their distance to the frontier) but by the movement of the frontier itself, which is pushed away by leading-edge innovators. The case of the knowledge investments.

The results reported in the last column of table 3 suggest only a minor role for the so-called "knowledge investment" term. In the DEA framework, this term is purported to capture the contribution of an increase in inputs per worker. The equivalent of this interpretation in the innovation framework developed here is an increase of innovation technologies at the wide economy level, given the size of the population. I interpret the low number reported in table 3 as to suggest that the accumulation of innovations is relatively a slow process.

\begin{tabular}{|c|c|c|c|c|}
\hline \multicolumn{5}{|c|}{ Table 3: GDP-Growth Decomposition (Average 1996-2008) } \\
\hline Country & GDP & Catching-up & Tech-change & K-Investment \\
\hline Argentina & 2.61 & 0.70 & 1.70 & 0.19 \\
\hline Austria & 2.25 & -0.20 & 2.40 & 0.05 \\
\hline Belarus & 8.35 & 5.60 & 2.60 & 0.00 \\
\hline Belgium & 2.10 & 0.00 & 2.10 & 0.00 \\
\hline Bulgaria & 5.24 & 2.50 & 2.50 & 0.17 \\
\hline Canada & 2.28 & 0.60 & 1.60 & 0.07 \\
\hline China & 7.35 & 10.30 & 8.00 & -9.88 \\
\hline Colombia & 1.36 & -0.50 & 190 & -0.03 \\
\hline Czech Republic & 3.22 & 0.60 & 2.50 & 0.10 \\
\hline Finland & 3.41 & 0.80 & 2.50 & 0.09 \\
\hline France & 1.56 & 0.20 & 1.10 & 0.25 \\
\hline Germany & 1.49 & 0.60 & 0.90 & -0.01 \\
\hline Hungary & 4.12 & 1.50 & 2.40 & 0.17 \\
\hline Ireland & 5.09 & 2.40 & 2.60 & 0.03 \\
\hline Israel & 1.51 & -0.80 & 2.30 & 1.57 \\
\hline Japan & 0.86 & 0.00 & -0.70 & 0.08 \\
\hline Latvia & 8.02 & 5.20 & 2.60 & 0.04 \\
\hline Lithuania & 6.44 & 3.70 & 2.60 & 0.02 \\
\hline Poland & 4.57 & 2.70 & 1.80 & -0.11 \\
\hline Portugal & 1.57 & -0.80 & 2.50 & 0.20 \\
\hline Romania & 3.43 & 1.00 & 2.20 & 0.00 \\
\hline Russian Federation & 5.85 & 4.80 & 1.00 & 0.10 \\
\hline Singapore & 3.11 & 0.40 & 2.60 & 0.22 \\
\hline Slovak Republic & 4.88 & 2.20 & 2.40 & -0.03 \\
\hline Slovenia & 4.41 & 1.80 & 2.60 & -0.03 \\
\hline South Korea & 3.83 & 2.70 & 1.20 & -0.10 \\
\hline Spain & 3.43 & 1.70 & 1.70 & 0.00 \\
\hline Turkey & 2.52 & 0.70 & 1.70 & 0.11 \\
\hline United Kingdom & 2.34 & 0.40 & 1.10 & 0.82 \\
\hline United States & 1.79 & 0.00 & 2.10 & -0.30 \\
\hline Mean & -3.63 & -1.69 & -2.15 & 0.20 \\
\hline
\end{tabular}

Thus, whilst capital deepening is an important component in the explanation of productivity growth, i.e., Kumar and Rusell (2002), the accumulation of innovation seems less substantial to explain per-capita growth in this paper. It seems cumbersome given the discussion at the outset of this paper. If innovation is such an important driver of economic growth, it is hard to understand the negligible contributions that are reported in table 3. Nevertheless, there are at least two reason to suggest that this is not necessarily inconsistent. First, relative to investment in capital assets, the share of expenditures on knowledge creation is smaller and relatively stable. In fact the highest ratios of expenditures on one of the most important components of innovation, R\&D, is registered in the most advanced countries. Second, it may be the case that a longer time period is needed for innovation expenditures to raise the GDP-growth performance of countries.

\subsection{Concluding remarks}


The endeavor of this paper has been focus on the empirical assessment of the relationship between innovation growth and per-capita GDP growth. The key insight behind the analysis borrows from the hypothesis of advantage of backwardness, which suggest a catching -up process in benefit of countries that fall backward of the world technology frontier. In this context, a simplified theoretical model that relates innovation to growth was settled-up. Under the lines of earlier related literature, the methodological approach has been based on a decomposition of growth into percentage changes attributable to the process of catching-up, technological change, and knowledge investments. The empirical results were brought out using a non-parametric method based on DEA techniques.

The analysis provide clear evidence that catching-up has been an important explanation of the growth dynamics of backward countries. Also, the results provide support to the idea that technological changes lead by advanced countries that push innovation at the world frontier - is an important explanation. In turn, the investment in knowledge, taking here as to represent the accumulation of innovations, has been found to play a rather negligible role in the decomposition analysis. These results are in sharp contrast with the findings in research that analyses labour productivity using a similar decomposition.

The dissimilarity, nevertheless, may be attributable to the fact that expenditures in innovation are relatively smaller and more stable than the investment in capital assets. Moreover, it has been argued that relatively longer periods of time might be necessary for investments in innovation to affect economic growth.

My final point is to acknowledge that the small sample of countries in which the analysis rely does not allow for making credible generalization. But certainly it provides a clue on the dynamics of the relationship between GDP growth and innovation. Further evidence and more precise insights on specific forms of innovation warrants more research.

\section{References}

Abramovitz, M. (1986). Catching Up, Forging Ahead and Falling Be- hind. Journal of Economic History, June. http://dx.doi.org/10.1017/S0022050700046209

Acemoglu, D. (2009). Introduction to Modern Economic Growth. The MIT Press.

Acemoglu, D., Zilibotti, F., and Aghion, P. (2006). Distance to Frontier, Selection and Economic Growth. Journal of the European Eco- nomic Association, 4(1), 37-74. http://dx.doi.org/10.1162/jeea.2006.4.1.37

Aghion, P., and Howitt, P. (2006). "Joseph Schumpeter Lecture" Appropriate Growth Policy: A Unifying Framework. Journal of the European Economic Association, 4(2/3), 269-314. http://dx.doi.org/10.1162/jeea.2006.4.2-3.269

Aghion, P., and Howitt, P. (2009). The Economics of Growth. The MIT Press.

Archibugi, D., Denni, M., and Filippetti, A. (2009). The Technological Capabilities of Nations: The State of the Art of Synthetic Indicators. Technological Forecasting \& Social Change. http://dx.doi.org/10.1016/j.techfore.2009.01.002

Barr, R. (2005). DEA Software Tools and Technology. A State of the Art Survey. University of Dallas, Unpublished.

Bernard, B., and Jones, C. (1996). Technology and Convergence. The Economic Journal, 106(437), 1037-44. http://dx.doi.org/10.2307/2235376

Coelli, T., Prasada, D., O'Donell, C., and Battese, G. (2005). An Introduction to Efficiency and Productivity Analysis. (Second Ed.), Springer.

Elsby, M., Michaels, R., and Solon, G. (2009). The Ins and Out of Cyclical Unemployment. American Economic Journal, Macroeconomics 1(1), 84-110. http://dx.doi.org/10.1257/mac.1.1.84

Gerschenkron, A. (1962). Economic Backwardness in Historical Per- spective. Harvard University Press.

Kumar, S., and Russel, R. (2002). Technological Change, Techno- logical Catch-Up, and Capital Deepening: Relative Contributions to Growth and Convergence. American Economic Review, 92(3), 527-48. http://dx.doi.org/10.1257/00028280260136381

Los, B., and Timmer, M. (2005). The 'Appropriate Technology 'Explanation of Productivity Growth Differentials: An Empirical Approach. Journal of Development Economics, 77(2005), 517-31. http://dx.doi.org/10.1016/j.jdeveco.2004.04.001

Nelson, R., and Pack, H. (1999). The Asian Miracle and Modern Growth Theory. The Economic Journal, 109(July), 416-36. http://dx.doi.org/10.1111/1468-0297.00455 
Nelson, R., and Phelps, E. (1966). Investment in Humans, Technological Diffusion, and Economic Growth. The American Economic Review, 56(1/2), 69-75.

Nelson, R., and Wright, G. (1992). The Rise and Fall of American Technological Leadership: The Postwar Era in Historical Perspective. Journal of Economic Literature, 30(4), 1931-64.

Van Ark, B., OMahony, M., and Timmer, M. (2008). The Productivity Gap Between Europe and the United States. Trends and Causes. Journal of Economic Perspectives, 22(1), 25-44. http://dx.doi.org/10.1257/jep.22.1.25

\section{Appendix}

Table 4: Description technology innovation

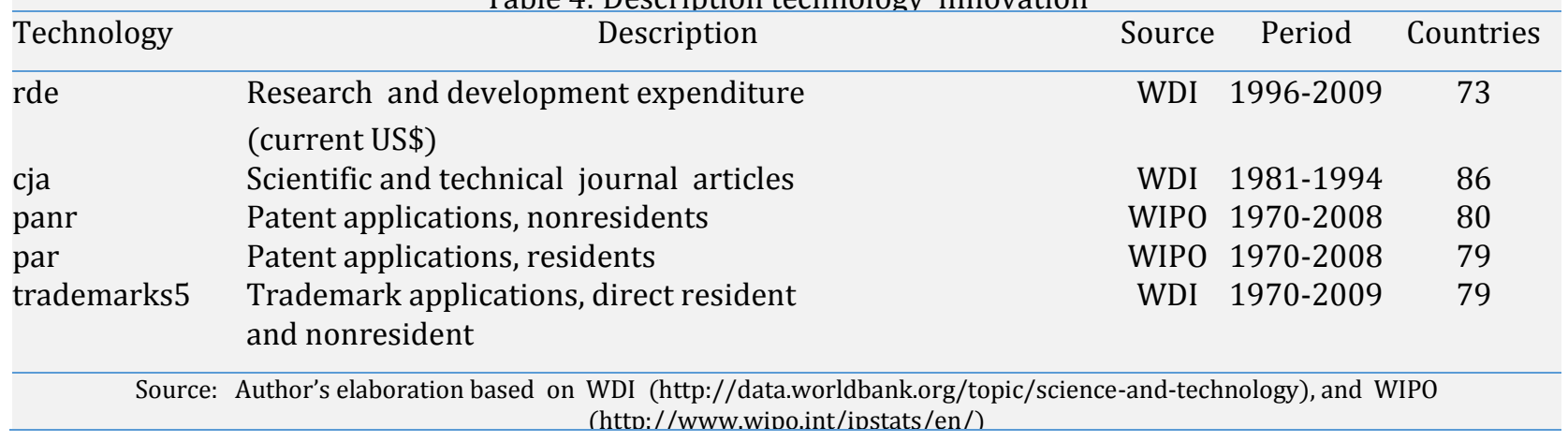

\section{Table 5: Countries in the Sample}

\begin{tabular}{lll}
\hline Argentina & France & Romania \\
Austria & Germany & Russian Federation \\
Belarus & Hungary & Singapore \\
Belgium & Israel & Slovak Republic \\
Bulgaria & Ireland & Slovenia \\
Canada & Japan & South Korea \\
China & Latvia & Spain \\
Colombia & Lithuania & Turkey \\
Czech Republic & Poland & United Kingdom \\
Finland & Portugal & United States \\
\hline
\end{tabular}

